the better form, but added the important improvement of separating the prisms and arranging them in segments."

Edinburgh, June 28.

D. A. Stevenson.

IN addition to several errors into which Mr. Kenward, in his third article on "Lighthouse Work," has fallen, he seems to have overlooked the experiments made by Messrs. Stevenson, in 1870 , on paraffin as an illuminant for lighthouses, and which were fully detailed in the Parliamentary Paper 3r8, Session r87I. Experiments had been made with some degree of success with burners having one and two wicks, but all attempts to burn paraffin efficiently in the large concentric-wick burners were unsuccessful until Capt. Doty solved the problem. Unaware of what had been done in France, Messrs. Stevenson, early in I870, had been conducting a train of experiments on paraffin, and had reached important conclusions on the subject, and good flames were got with the single and double Argand lamps, when Capt. Doty submitted his burners to them. The Doty burners were then subjected to crucial tests in Edinburgh, and also to actual trial for a month in a first-order lighthouse. The conclusions Messrs. Stevenson then arrived at and reported to the Scottish Lighthouse Board may be summarized as follows: that paraffin as now manufactured, with a high flashing-point, is safe and suitable as a lighthouse illuminant; the flames of the Doty burners are of great purity and intensity, and easily maintained at the standard height ; the lamp-glasses and lamps in use for colza are equally suitable for paraffin; the varying state of the atmosphere does not affect the penetrability of the paraffin light more than the colza light; no structural alterations on the existing apparatus are necessary ; the initial power of the lights will be exalted from ro per cent. in the four-wick burner to fully Ioo per cent. in the single-wick burner; and that the use in the Scottish lighthouses of the new illuminant would effect an annual saving of $£ 3478$. These conclusions, which subsequent experience has fully borne out, settled the relative merits of paraffin and colza so far as British lighthouses were concerned; and the first four-wick paraffin burner ever permanently installed in a lighthouse was at Pentland Skerries on February 15, 187 I, while Argand paraffin burners were in use at Pladda in Decembe $\mathbf{r} 870$, and at the catoptric lights of Great Castle Head in December I870, and at Flamborough Head in June 1872.

With reference to Ailsa Craig the facts are that in 1878 , when Messrs. Stevenson were considering the problem of effectively guarding the Fair Ysle by fog-signals, they consulted Prof. Holmes as to the feasibility of working the signals from a central station and sending the compressed air through a long length of piping, and he concurred with them regarding its practicability, and stated that he had worked a signal in Canada at a distance of half a mile. When Ailsa Craig came to be dealt with, the Fair Isle scheme was reverted to, and Mr. Ingrey's firm contracted to carry out the work in accordance with Messrs. Stevenson's specification. The automatic appliances for securing the true periodicity of the siren blasts were designed by Mr. Ingrey.

In giving the history of gas-engines applied as a motive power for actuating fog-signals, a most important advance in lighthouse work, Mr. Kenward does not state that this was done on the Clyde by Messrs. Stevenson in 1875, and that since then they have introduced gas made from mineral oil for driving gasengines at Langness in $\mathbf{1} 880$, at Ailsa Craig, and at the Clyde.

84 iGeorge Street, Edinburgh, July 4. D. A. Stevenson.

\section{The Use of Flowers by Birds.}

I HAVE just read in NATURE of June 23 (p. 173) Mr. W. White's letter, and should like, with your permission, to add a few words on this subject. A quiet, leafy home has made me well acquainted with the commoner birds, therefore I speak. In the first place, with regard to the non-protective colour of the laburnum blossoms, it must be remembered that the flowers thus used have two other qualities that recommend them to the nest-builders : flexibility and length. Everyone must have noticed how sparrows and other birds steal anything long and limp-pieces of string, \&c. - when they are building. Only the other day I caught a sparrow trying hard to untie a piece of thick string with which the branch of a tree had been tied back, and it would have succeeded if $\mathrm{I}$ had not gone to the rescue. I have had the ties of budded roses taken away by them also. I have been told by a lady that she once lost a lace handkerchief in a mysterious manner, which was at last discovered-through a telescope- on a high tree, on the nest of a rook or daw. All the flower-sprays mentioned were long and limp. I have seen birds take those of the clematis also.

But there can be no doubt that birds have a very keen sense of the protectiveness of colour; if you startle a blue tit it will seek a high branch against the sky-blue, and brown, and green; a robin flits away to the brown shadow of a bush; I have even known a young robin, threatened by an elder (they are great disciplinarians), take refuge near a reddish-brown dress.

A thrush is wonderfully clever almost as soon as it is fledged in finding its own tints on some wall or tree-trunk, and making believe to be a piece of it to such an extent that one may approach quite close to it and it will remain absolutely motionless as long as one's eye is upon it ; but if the eye is removed, even for a "twinkling," the bird will have hopped down noiselessly behind something before one can look again.

With respect to the yellow flowers, may there not be some quality attached to the colour that birds like, or find profitable? I have watched a thrush during a long hard frost, devour - not merely pull to pieces, but eat voraciously-large bunches of yellow crocuses. All the earlier bunches were eaten. When the purple and white came out later it was still faithful to the yellow, and never touched any other; and so eager was it, that when the blossoms were gone it would dig its beak down into the buds and pull out the least bit of yellow that appeared. I watched it from a window close above the bed, and there was no possibility of making any mistake about it. The bird-a very large one-took some again this year, but not many. It could hardly be all for love of colour, though no doubt that is very strong in birds as in children. Birds are very like children.

The sparrows mentioned in my last note made two more trials after I sent it-five in all ; and the last time their attempt was nearly composed of white alyssum. After that they gave it up, but I get a severe scolding from them sometimes if I go near the place. They tried to build there last year, and I removed two or three nests, but I allowed a thrush, that had built below and brought forth a brood before I perceived it, to remain. When they left, the sparrows immediately built on the top of the forsaken thrush's nest. They seem to have drawn the conclusion-rather hastily, but not irrationally-that that was a safe place, and whether or not their thoughts took the shape of words, they chattered over their work immensely. And I do not know where the line can be drawn between words and exclama. tions (the foundation-stones of language), nor between those and the notes and cries of birds, which are much more numerous and varied and distinctive of purpose than most people imagine, especially those of the robin. The strangely human and canine cries of a party of quarrelling sea-gulls are extremely expressive.

It may be said that there is no progress, no addition to the language of birds ; but I am not sure of that. Last winter, a robin, accustomed to be fed at my window on bits of bacon, invented a note by which it called me to feed it. It was quite peculiar-hushed, short, and muttered, as it were. Its object seemed to be to reach my ear and not that of rival birds. It would take a few little bits-very few-when offered, look gratefully in my face, with its head on one side, and away, till it was again hungry; then-da capo. The same robin is hopping in and out of the open window continually now, taking what it pleases for itself and young of food set for it.

That birds should be subject, like ourselves, to the tyranny of fashion seems not at all unlikely if one considers the nature of that tyranny. The feeling that seems to oblige people to adopt, notwithstanding their sense of beauty and fitness, fashions that are positively monstrous, must have its roots low down in the scale of Nature. It seems to be composed of a sense of association and a love of the accustomed-both very strong in birds ; association, for instance, of wisdom and authority with a wig, of the delightfulness of well-bred women with the extremely undelightful outlines they contrive to give to their figures, \&c., \&c. The pleasure that the accustomed gives is, I suppose, that of rest. No doubt fashion may reign in the lower regions may it not control, in a somewhat transient manner, the bee that packs its load from the pollen of a particular flower, of one colour and no other?

Sidmouth, July 3 . 